\title{
Teleomorph and Anamorph Relationships in Marine Ascomycetes (Halosphaeriaceae) ${ }^{1}$
}

\author{
A. Nakagiri and K. Tubaki \\ Institute of Biological Sciences, The University of Tsukuba, Ibaraki, 305 Japan
}

(Accepted December 12, 1984)

\begin{abstract}
Studies of the halosphaeriaceous fungi revealed six teleomorph-anamorph relationships: Corollospora pulchella - Clavariopsis bulbosa, Corollospora luteola - Sigmoidea luteola, Corollospora intermedia - Varicosporina sp., Halosphaeria mediosetigera - Trichocladium achrasporum, Halosphaeria cucullata - Periconia prolifica and Lindra obtusa - Anguillospora marina.
\end{abstract}

A number of characters have been used in the taxonomy of the Halosphaeriaceae. Recently, particular attention has been devoted to ascospore appendage ontogeny. In this paper we examine ascospore ontogeny, conidial development of anamorphs and the peridial structure of the ascocarps. The latter, along with ascospore appendage ontogeny, have been found to be stable characters and can be used in the separation of genera within the Halosphaeriaceae.

In addition, the geographical distribution of several marine fungi was found to be related to their morphs as follows; those strains with only teleomorphs are distributed in the lower temperature regions, those with anamorphs only in the higher temperature regions while those with teleomorphs and anamorphs are distributed in the intermediate regions.

Seasonal alternation of morphs was also observed in C. intermedia; the teleomorph occurring predominantly during the winter and the anamorph during spring through to the autumn.

\section{Introduction}

One of the most important problems in the taxonomy of the Halosphaeriaceae concerns the taxonomic criteria to be used in delimiting genera and species. Proposals for the delimination of genera have been submitted by Barghoorn and Linder (1944) who delimited genera by ascospore morphology, ascospore appendage and ascocarp characters, while Cavaliere $(1966 \mathrm{a}-\mathrm{c})$ placed emphasis on spore pigmentation and septation for generic separation, and features of spore size and appendage morphology for the separation of species.

At present, there are two schools of the thought concerning the delimination of genera in the Halosphae-

1 Contributions from the Shimoda Marine Research Center, The University of Tsukuba, No. 454. riaceae. Kohlmeyer $(1960,1972)$ suggested that greater importance should be attached to the morphology and structure of ascocarps in the taxonomy of genera. He recognized that ascocarp wall, neck, pseudoparenchyma and ascus structure were useful characters in taxonomy. On the other hand, Jones and Moss (1978, 1980) and R. G. Johnson (1980), on the basis of scanning and transmission electron microscopy (SEM, TEM) observation, considered the type of ascospore appendage ontogeny to be of greater importance in delimiting genera. They distinguished several types of appendage ontogeny such as, fragmentation of the exosporium (or sheath), outgrowth of the spore wall, and exudation of mucilaginous substance. However, there is still the question as to whether the delimitation of the genera should be based solely on appendage ontogeny. 


\section{Materials and Methods}

Taxonomic considerations of generic criteria in the Halosphaeriaceae

Many strains of the halosphaeriaceous fungi which have teleomorph-anamorph relationships were obtained from the Japanese coast by incubating driftwood, submerged wood and cast seaweed in moist chambers or baiting beach sand with balsa wood, or by isolating spores from sea foam using a Skerman micromanipulator (Nakagiri and Tubaki 1982). For $H$. cucullata and $P$. prolifica, as they were not isolated in this study, we referred to the descriptions given by Kohlmeyer and Kohlmeyer (1965, 1969).

a) Observation of ascospore and appendage ontogeny under the scanning electron microscope

A modified Moss and Jones (1977) method for SEM was employed. Ascocarps produced in nature, or in culture, were placed in a $0.1 \mathrm{M}$ sodium cacodylate buffer ( $\mathrm{pH} 7.2$ ) containing $2 \%$ sodium chloride in order to adjust the osmolarity and were dissected to obtain a suspension of mature or immature ascospores. Suspensions were pipetted onto the surface of $1.0 \mu \mathrm{m}$ pore size, $25 \mathrm{~mm}$ diam Nuclepore Polycarbonate membranes (Nuclepore Corp., U.S.A.) and the buffer drawn through the membranes by an underlayer of filter paper. Spores attached to the membranes were fixed with $1 \%$ osmium tetroxide in the buffer for $12 \mathrm{~h}$ at $4{ }^{\circ} \mathrm{C}$. Fixed material was washed in buffer and dehydrated in a graded ethanol series; 30 , $50,70,80,90,95$ and $100 \%$ (15 min in each). Following complete dehydration and substitution by isoamyl acetate, the membranes and attached ascospores were critically-point-dried in a Hitachi Critical Point Drier. Dried membranes were gold coated in a JEOL Ion Sputter JFC-1100 and examined JEOL Scanning Microscope JSM-T20 or JSM-25.

b) Observations of conidia and conidiophores under scanning electron microscope

The procedure of Cole and Samson (1979) was followed to fix the mycelia and conidia on agar medium. Fixed specimens were washed in buffer and dehydrated in a graded ethanol series. After complete dehydration and substitution by isoamyl acetate, the specimens were critically-point-dried, gold coated and observed as mentioned above.

\section{c) Observations of peridial structure}

The ascocarps of 24 species of the Halosphaeriaceae, produced both in natue and culture, were examined in order to elucidate peridial structure. Thin sections of the ascocarps were made with a freezing microtome (Yamato Koki, Japan), and observed under the light microscope. Peridial structure of ascocarps attached to sand grains were observed under the SEM. Procedures for fixation, dehydration and critical point drying were almost the same as those used for the ascospores. Completely dried ascocarps were positioned on the stubs with double-sided adhesive tape and split with a razor blades. After coating with gold, the cut ends of the peridia were observed under the SEM. The results for eight fungi only are presented in this paper.

Studies of the relationships between the geographical distribution and life histories

a) Plotting fungal distribution

On the Hughes' zonal ocean map (Hughes 1974), the geographical distribution of the teleomorph-anamorph fungi; $C$. pulchella $-C l$. bulbosa, $C$. intermedia - Varicosporina sp. and H. mediosetigera $-T$. achrasporum, were plotted to investigate the distributional patterns of their teleomorphs and anamorphs. Distribution maps were based on the publications of Jones (1968), Kohlmeyer and Kohlmeyer (1971), Kumar (1973), Hughes (1974), Schaumann (1975), Gorter (1978), Kohlmeyer (1980), Booth (1981, 1983), Koch (1982), Koch and Jones (1983), Kirk (1983), and our own data from Japan.

\section{b) Examination of cultures}

Growth and reproductive properties of the abovementioned fungi were examined at different temperatures. Precultured inocula on SWSs-20 (soluble starch $1 \%$, soytone $0.1 \%$, agar $1.8 \%$, artificial seawater (Jamarin S, Jamarin Lab., Japan) 20\% salinity, $\mathrm{pH} 8.2$ ) were cut into $4 \mathrm{~mm}$ diam agar disks with a cork borer and inoculated onto the same component test media. Triplicated test plates were incubated at $10,15,20,25,30,35$ and $40^{\circ} \mathrm{C}$. After 2 weeks of incubation, colony diam was measured. Conidium formation was examined after 7 weeks of incubation. Perithecium formation was also examined after two or three months of incubation, but $C$. pulchella strain did not produce perithecia on any of the agar media.

Species and strains tested are shown with their original localities as follows:

C. pulchella - Cl. bulbosa: AN-553, Itsugahama, Echigonanahama, Niigata Pref.; AN-801, Mokuzu, Sukumo, Kochi Pref.; AN-820, Ukibuchi, Okata, 
Kochi Pref.; AN-661, Nabeta Bay, Shimoda Shizuoka Pref.; AN-847, Kesaji River, Okinawa Pref. (transferred from Dr. Nakamura).

C. intermedia - Varicosporina sp.: H-768, Helgoland, West Germany (transferred from Dr. Schaumann, KMPB, H-768); AN-632, 756, Shirahama, Shimoda, Shizuoka Pref.

H. mediosetigera - T. achrasporum: AN.607, Teradomari, Niigata Pref.; AN-778, Iwaji Matsuzaki, Shizuoka Pref.; AN-611, Ushimado, Oku Okayama Pref.: AN-846, Itsugahama, Echigo-nanahama, Niigata Pref.

c) Examination of seasonal alternation of morphs

Foam samples collected at Shirahama beach, Shimoda, Shizuoka Pref., central Japan, were periodically examined for the occurrence of ascospores and/or conidia of $C$. intermedia in the foam. Single spores were isolated and cultured for the precise identification. The alternation of the morphs was estimated from the occurrence of the spores in the foam samples.

\section{Results and Discussion}

Teleomorph-anamorph relationships and their contribution to the taxonomy of genera

a) Teleomorph-anamorph relationships in the $\mathrm{Ha}$ losphaeriaceae

Of about 60 species in the Halosphaeriaceae, only six teleomorph-anamorph relationships have been hitherto discovered. Shearer and Crane (1971, 1977) described the Corollospora pulchella - Clavariopsis bulbosa, Halosphaeria mediosetigera - Trichocladium achrasporum connections. The Halosphaeria cucullata - Periconia prolifica connection was found by Kohlmeyer (1969).

In addition to these known examples, we have discovered the following three teleomorph-anamorph relationships: Corollospora luteola - Sigmoides luteola (Nakagiri and Tubaki 1982), Corollospora intermedia - Varicosporina sp. (unpublished data) and Lindra obtusa - Anguillospora marina (Nakagiri and Tubaki 1983).

\section{i) Corollospora pulchella - Clavariopsis bulbosa connection}

Ascospores of $C$. pulchella are provided with appendages at both ends and around the central septum (Fig. 1), and develop by fragmentation and peeling off of a sheath. Appendage development is the same as that described for $C$. maritima, $C$. intermedia and C. lacera (Jones and Moss 1978, 1980). Cl. bulbosa shows sympodial conidium development (Fig. 2). Several stauroform conidia are produced successively as the conidiophore proliferates sympodially (Fig. $3)$. Another type of conidium which consist of only a single arm was observed by Koch (1982). We also observed them in Japanese strains and found that they were produced often when the cultures were incubated at higher temperatures, $35-40{ }^{\circ} \mathrm{C}$. Since the development of the single arm conidia is the same as that of stauroform conidia, the former should be considered to be an irregular form of the latter.

When $\mathrm{Cl}$. bulbosa was originally described by Anastasiou (1961), its conidia were described as aleuriosporic. Anastasiou regarded this fungus as belonging to the genus Clavariopsis. On the other hand, Webster and Descals (1979) reported that Clavariopsis aquatica de Wildeman, the type species of the genus, produces conidia by percurrent proliferation. They also discovered its teleomorph to be a loculoascomycetous fungus, Massarina sp. (Table I). Cl. bulbo$s a$ shows sympodial conidium development and has a pyrenomycete teleomorph. Accordingly, the genus Clavariopsis appears to be heterogenous and $\mathrm{Cl}$. bulbosa should be transferred to another genus. Marvanová (1980) pointed out the heterogeneity of the genus Clavatospora S. Nilsson and redefined it on the basis of conidium development. She emended the generic description of Clavatospora, that conidium development is holoblastic with conidiogenous cells proliferating sympodially or rarely percurrently at the apex. Clavatospora S. Nilsson ex Marv. et Nilsson includes Clavatospora longibrachiata (Ingold) S. Nilsson, the type species of the genus, which is a freshwater hyphomycete, and has tetraradiate conidia consisting of a clavate axis and three, thin, divergent, simultaneous apical appendages, and another type of aerial conidium. Since Clavariopsis bulbosa is similar to Clavatospora longibrachiata in

Table I. Conidium development and teleomorph of Clavariopsis species

\begin{tabular}{lll}
\hline & Conidium development & Teleomorph \\
\hline $\begin{array}{ll}\text { Clavariopsis aquatica de Wildeman } 1895 \\
\text { Cl. brachycladia Tubaki 1957 }\end{array}$ & $\begin{array}{l}\text { percurrent proliferation } \\
\text { terminal holoblastic }\end{array}$ & Massarina sp. (Loculoascomycetes) \\
sl. bulbosa Anastasiou 1961 & sympodial & C.pulchella (Pyrenomycetes) \\
\hline
\end{tabular}




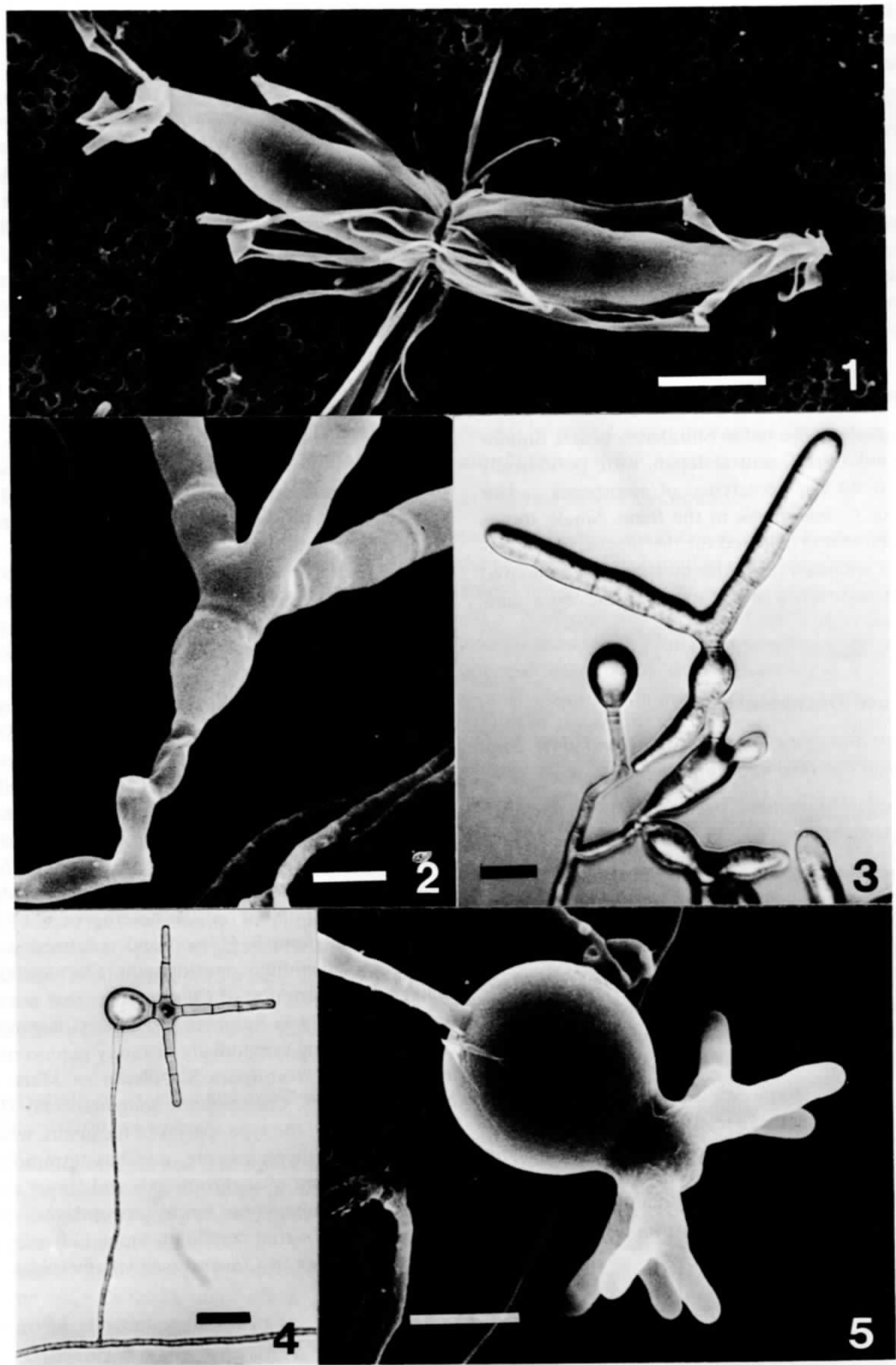

Figs 1-5.

Fig. 1. Corollospora pulchella, scanning electron micrograph. Ascospore with equatorial and polar appendages which develop by fragmentation and peeling off of an exosporium. Figs 2-3. Clavatospora bulbosa, scanning electron microscopy and light microscope micrographs. Conidia and conidiophore showing sympodial conidial formation. Figs 4-5. Orbimyces spectabilis, light microscope and scanning electron micrographs. Conidia produced singly on conidiophore.

Bar lines: Figs 1, 3, $5=10 \mu \mathrm{m}$; Fig. $2=5 \mu \mathrm{m}$; Fig. $4=20 \mu \mathrm{m}$. 
conidium morphology and conidium development, we propose a new combination, in spite of differences in aerial conidium production, their habitats and in that the conidia of the former species are pigmented while those of the latter are hyaline.

Clavatospora bulbosa (Anastasiou) Nakagiri et Tubaki, comb. nov.

$\equiv$ Clavariopsis bulbosa Anastasiou, Mycologia $53: 11,1961$

Clavatospora bulbosa has been considered to be possibly related to Orbimyces spectabilis Linder (Kohlmeyer and Kohlmeyer 1979), but O. spectabilis has a terminal holoblastic conidium development (Figs 4-5). Consequently, a relationship between them cannot be suggested at present.

\section{ii) Corollospora luteola - Sigmoidea luteola connec-} tion.

Ascospore appendages are formed (Fig. 6) as described for $C$. pulchella. The anamorph of $C$. luteola is $S$. luteola which produces sigmoid and multiseptate conidia successively on denticles (Fig. 7). This type of condial development is considered to be not typical but is sympodial (Nakagiri and Tubaki 1982).

\section{iii) Corollospora intermedia - Varicosporina sp. connection}

This connection is newly recorded as Japanese isolates of $C$. intermedia were found to have a Varicosporina anamorph (Fig. 8). Ascospore appendage ontogeny in $C$. intermedia is the same type as in C. pulchella and $C$. luteola, except for posessing terminal, thorn-like appendages (Fig. 9). Conidia similar to those of $V$. ramulosa Meyers et Kohlm. are produced successively as the conidiophore proliferates sympodially (Fig. 10), and this anamorph will be described as a new species of the genus Varicosporina.

\section{iv) Halosphaeria mediosetigera - Trichocladium achrasporum connection}

Ascospore appendages of $H$. mediosetigera are attached at both ends and at the central septum (Fig.
11), and develop by fragmentation and peeling off of the exosporium (Moss and Jones 1977). However, appendage ontogeny of this species is different from that of Corollospora as the exosporium peels off spirally in $H$. mediosetigera (Fig. 11). TEM studies (R. G. Johnson 1980) also revealed other differences in sheath structures between them (Jones, R. G. Johnson and Hoss 1983, 1984).

Shearer and Crane (1977) reported that the U.S.A. strains of the teleomorph were provided with a $T$. achrasporum anamorph, but this has not been observed in Japan. The conidia are dark in colour, 3 to 4 celled and are produced singly on the conidiophores (Fig. 12). Conidium development is terminal holoblastic.

\section{v) Halosphaeria cucullata - Periconia prolifica con- nection}

Ascospores are cylindrical, one-septate with a caplike appendage at one end. The appendage is deciduous and composed of a gelatinous substance. Appendage ontogeny has never been confirmed with SEM or TEM observation, but, the mucous and deciduous appendage is apparently different from that of $H$. mediosetigera. However, it is necessary to examine the specimen by electron microscopy to determine appendage ontogeny. The anamorph is $P$. prolifica which produces subglobose conidia acropetally and conidium development is of the blastocatenate type.

\section{vi) Lindra obtusa - Anguillospora marina connec- tion}

Ascospores of L. obtusa are filiform, curved, multiseptate and lacking appendages (Fig. 13). The anamorph is A. marina which produces filiform, multiseptate conidia successively on the conidiophore. The latter proliferate through the scar percurrently (Fig. 14). SEM micrographs show the scars at septa where conidia were detached (Fig. 15). Conidium development is a percurrent proliferation.

The observations on ascospore appendage and conidium development are summarized in Table II.

Table II. Ascospore appendage ontogeny and conidium development of teleomorph-anamorph species in the Halosphaeriaceae

\begin{tabular}{lll}
\hline Teleomorph - Anamorph & Appendage Ontogeny & Conidium Development \\
\hline Corollospora pulchella - Clavatospora bulbosa & fragmentation of exospore & sympodial \\
Cl. luteola - Sigmoidea luteola & fragmentation of exospore & sympodial \\
C. intermedia - Varicosporina sp. & fragmentation of exospore & sympodial \\
Halosphaeria mediosetigera - Trichocladium achrasporum & spiral framentation of exospore terminal holoblastic & blastocatenate \\
H. cucullata - Periconia prolifica & ? (mucous appendage) & percurrent proliferation \\
Lindra obtusa - Anguillospora marina & - &
\end{tabular}




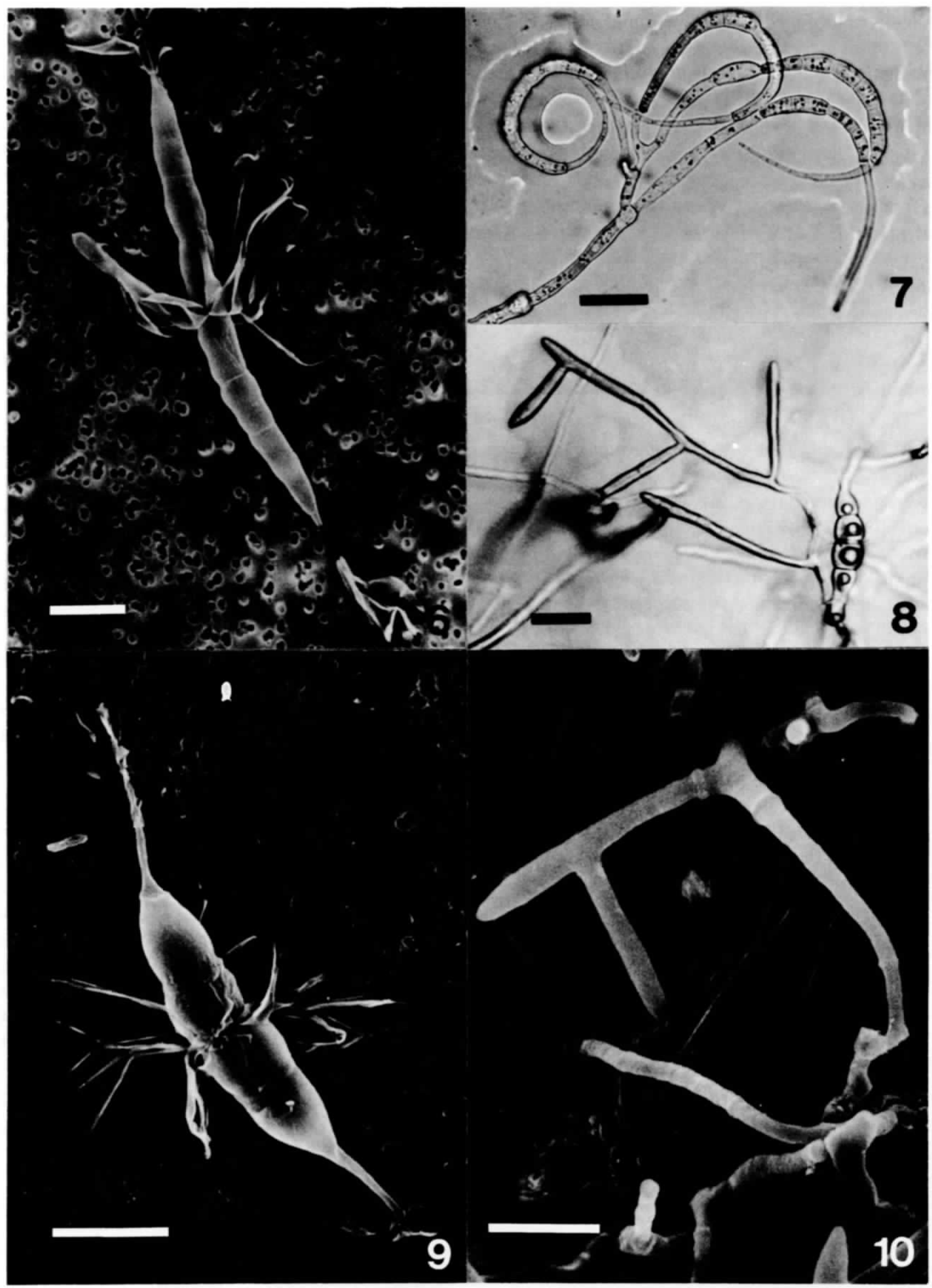

Figs 6-10.

Fig. 6. Corollospora luteola, scanning electron micrograph. Ascospore with equatorial and polar appendages which are developed by fragmentation and peeling off of an exosporium. Fig. 7. Sigmoidea luteola, light microscope micrograph. Conidia produced on denticles of conidiophore. Fig. 8. Corollospora intermedia, light microscope micrograph. Ascospore germination and formation of branched conidium on hypha. Fig. 9. Corollospora intermedia, scanning electron micrograph. Ascospore with equatorial exosporic appendages and terminal thorn-like appendages with polar inverted appendages. Fig. 10. Varicosporina sp., scanning electron micrograph. Branched conidium produced on denticle of conidiophore which proliferates sympodially.

Bar lines: Figs 6, 9, $10=10 \mu \mathrm{m}$; Figs 7, $8=20 \mu \mathrm{m}$.

Botanica Marina / Vol. XXVIII / 1985 / Fasc. 11 

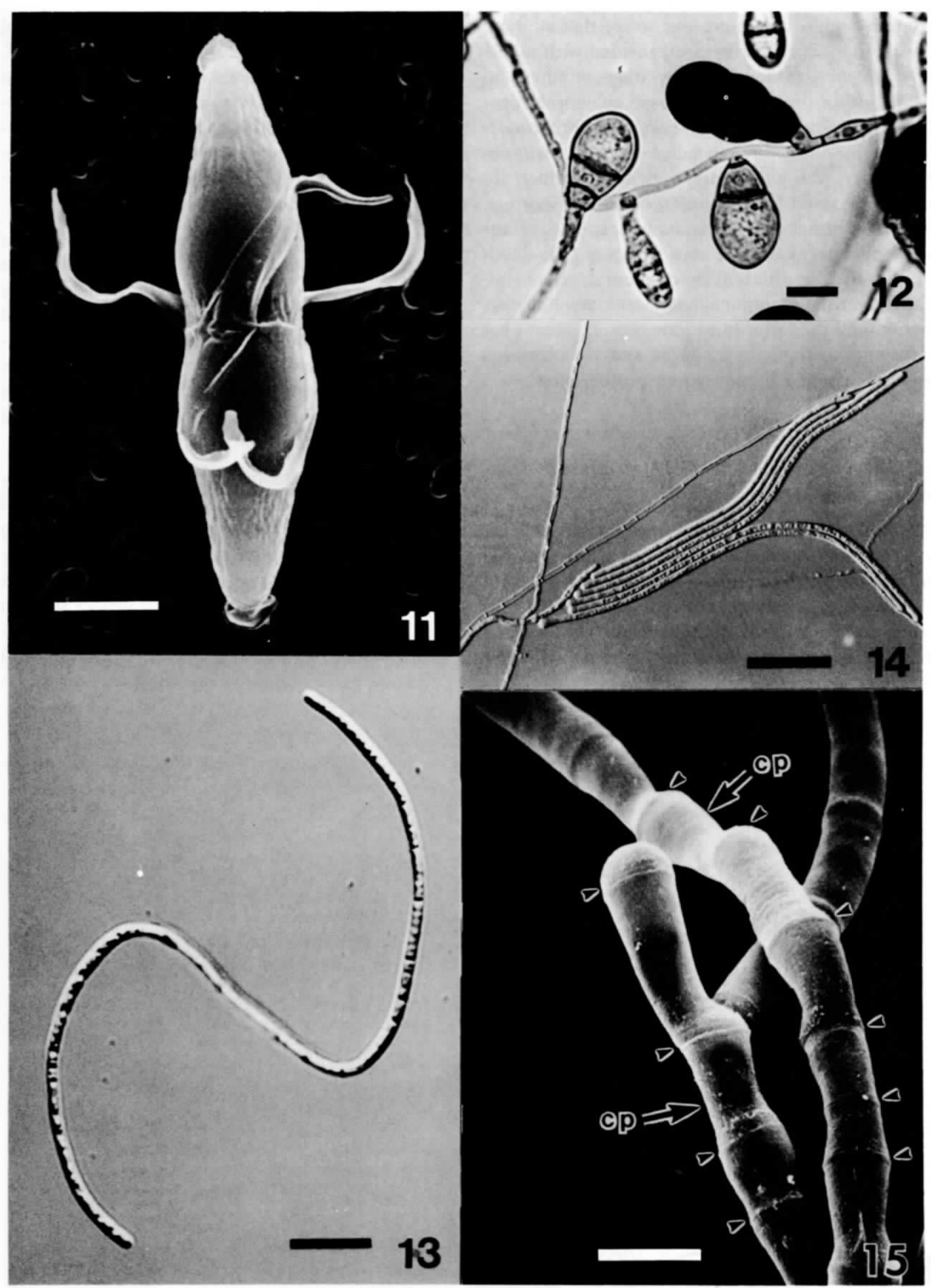

Figs $11-15$

Fig. 11. Halosphaeria mediosetigera, scanning electron micrograph. Ascospore with equatorial and polar appendages. Equatorial appendages are formed by spiral fragmentation and peeling off of an exosporium. Fig. 12. Trichocladium achrasporum, light microscope micrograph. Holoblastic conidium produced terminally on short conidiophore. Fig. 13. Lindra obtusa, light microscope micrograph. Multiseptate ascopore. Fig. 14. Anguillospora marina, light microscope micrograph. Conidia produced successively on conidiophore which proliferate percurrently. Fig. 15. A. marina, scanning electron micrograph. Septate conidiophore (arrowed cp) with serial production of conidia (arrows indicate scars where conidia were detached).

Bar lines: Fig. $11=5 \mu \mathrm{m}$; Fig. $12=10 \mu \mathrm{m}$; Figs $13,14=20 \mu \mathrm{m}$; Fig. $15=5 \mu \mathrm{m}$. 
From this table, it is interesting to see that all three Corollospora species that are provided with ascospore appendages developed by fragmentation and peeling off of the exosporium have anamorphs producing conidia sympodially. Two species of Halosphaeria show different appendage types. H. mediosetigera has apical and central appendages which are formed by spiral fragmentation of the exosporium. On the other hand, H. cucullata has cap-like, gelatinous appendages at one end of the spore. Their anamorphs are also different in conidium development. The former shows terminal holoblastic conidium formation and the latter blastocatenate. L. obtusa has ascospores without appendages and its anamorph produces conidia by percurrent proliferation.

b) Evaluation of ascocarp peridial structure as a taxonomic character.

The structure of the peridium in C. maritima, in ascocarps obtained from nature and in culture differed in thickness of the peridium and cell wall (Figs 16, 17). However, they were both composed of flat cells inside and round cells to the outside. This suggests that the layered structure of the peridium is a stable character and useful in taxonomy.
The peridial structures in $C$. pulchella, C. luteola and C. intermedia (Figs 18-20) are similar to that in $C$. maritima. These are species whose life histories were revealed and found to be provided with the same ascospore appendage ontogeny and anamorphs showing the same conidium development. This also suggests the reliability of the peridial feature in the taxonomy of the genus.

On the other hand, C. trifurcata differs from other species of the genus in peridial structure and also in appendage type (Figs 21-23). The former is very thin and composed of three to four layers of small cells. The appendage is considered to occur by outgrowth of the spore wall (Jones and Moss 1978). From this, it is concluded that the species should be removed from the genus Corollospora as proposed by Jones et al. (1983).

Some modificatioins of peridial structure were observed in several undescribed species of the genus Corollospora. In Corollospora sp. 1, Corollospora sp. 2, and Corollospora sp. 3, ascospores are provided with " $C$. maritima" type appendages (Figs 24 , $26,28)$. Peridial structures of these species show an outermost layer of peculiar large cells in Corollospora sp. 1 and Corollospora sp. 2 (Figs 25, 27), or a prosenchymatic outermost layer in Corollospora sp.
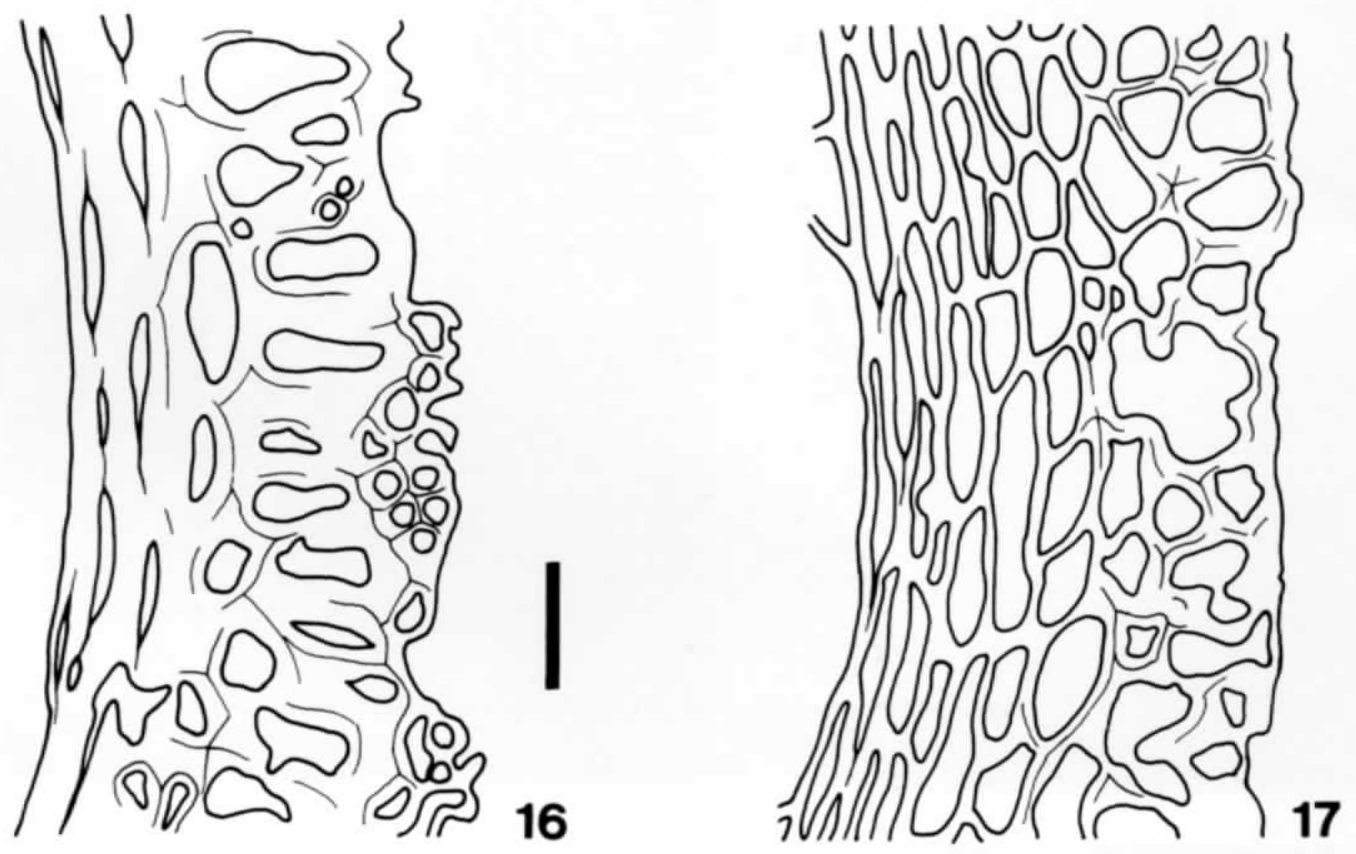

Figs 16-17. Ascocarp peridial structures of Corollospora maritima. Line drawings.

Fig. 16. Peridial structure of ascocarp produced in nature. Fig. 17. Peridial structure of produced in culture. 

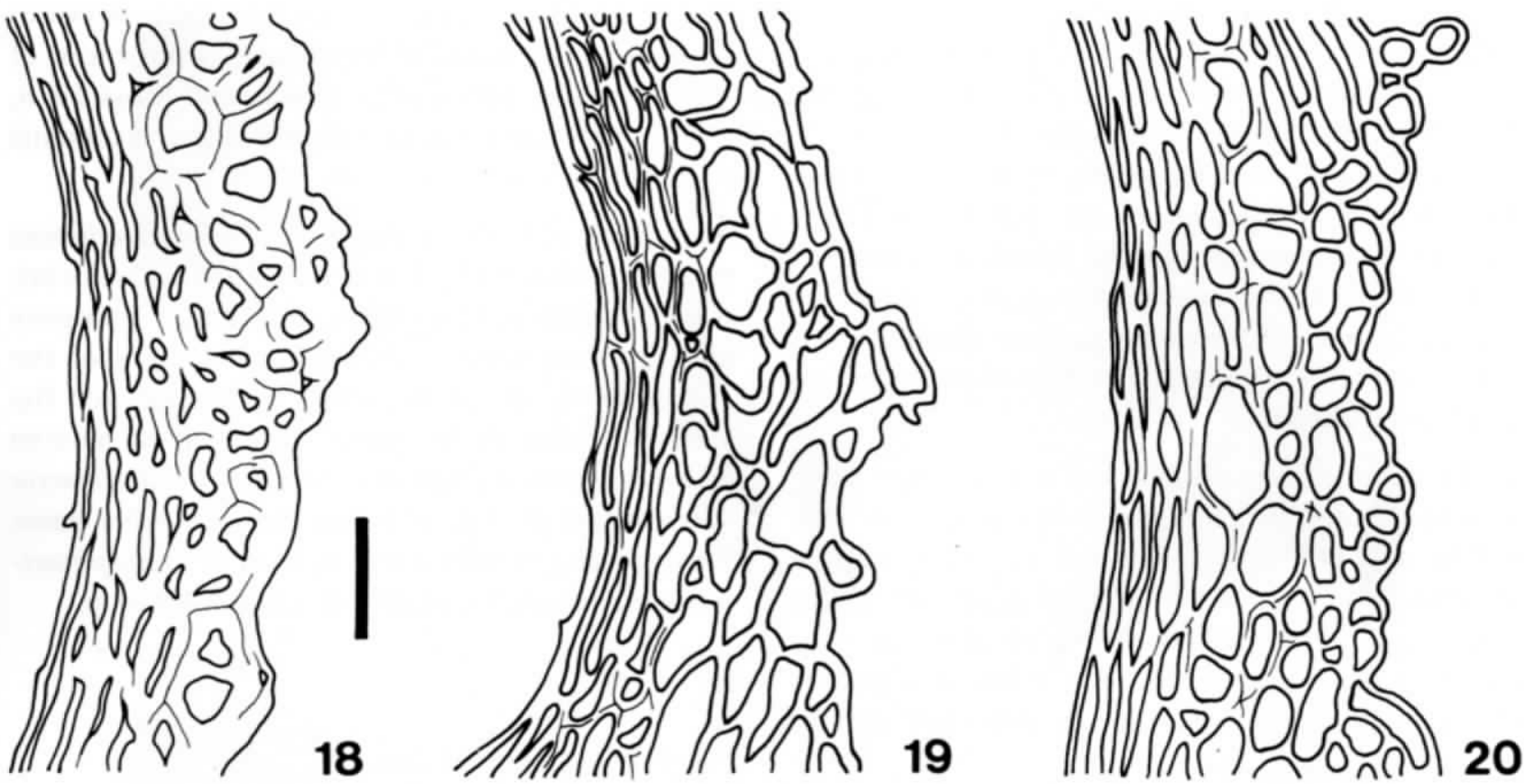

Figs 18-20. Ascocarp peridial structure of Corollospora species. Line drawings. Fig. 18. C. pulchella. Fig. 19. C. luteola. Fig. 20. C. intermedia. Bar line $=10 \mu \mathrm{m}$.
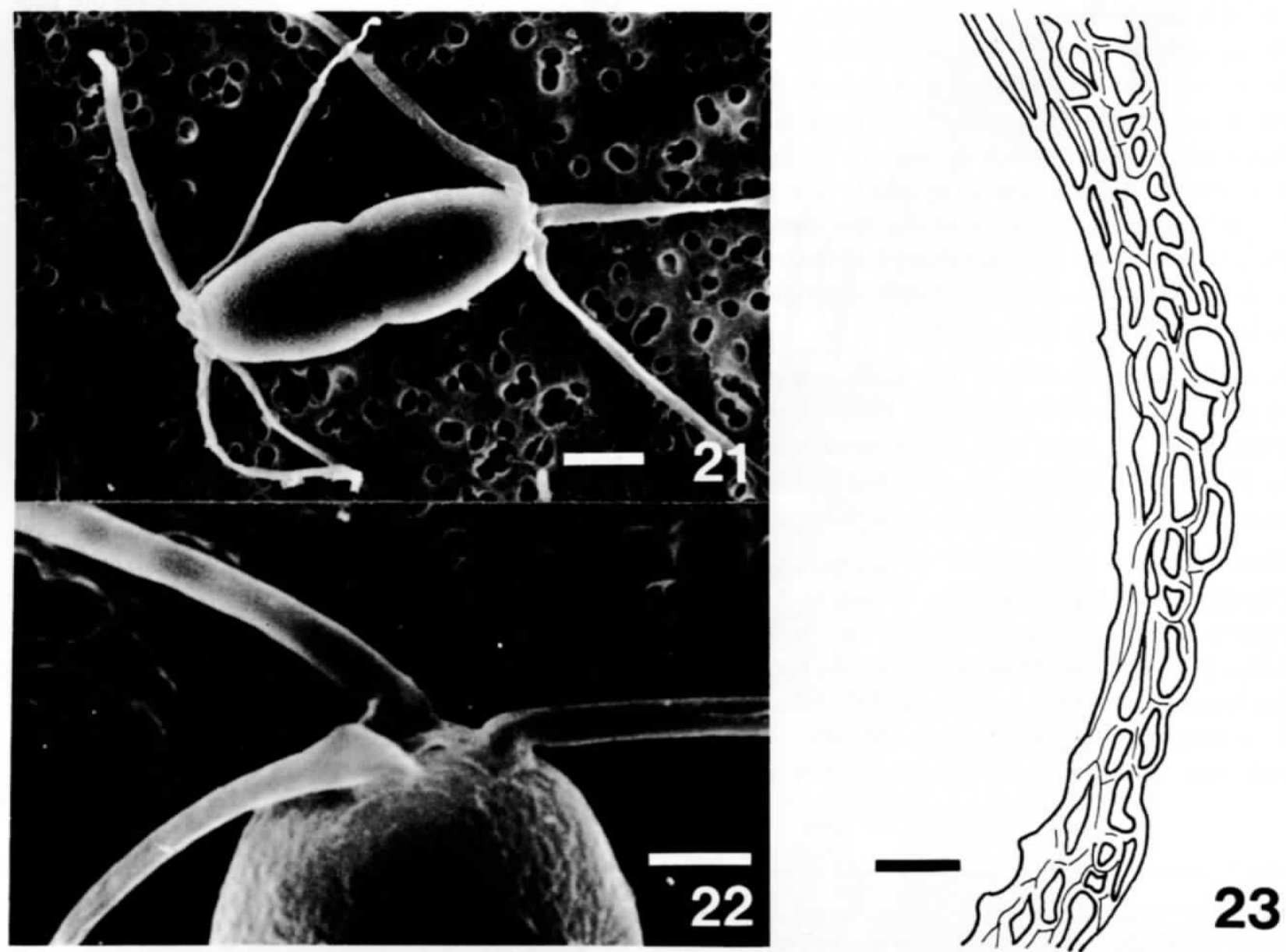

Figs 21-23. Corollospora trifurcata.

Fig. 21. Scanning electron micrograph. Ascospore with terminal appendages. Fig. 22. Scanning electron micrograph. Ascospore apex with bulbous bases of appendages which developed as outgrowths of the spore wall. Fig. 23. Ascocarp peridial structure. (line drawing) Bar lines: Fig. 21, $23=5 \mu \mathrm{m}$; Fig. $22=2 \mu \mathrm{m}$ 
3 (Fig. 29). However, the inner layers show the same pattern as that of other Corollospora species: flat cells at the inside and rounded cells to the outside. Therefore, the common peridial structure is observed in all species of the genus, though some minor differences may exist in several species. Modifications of the outermost peridial layers are restricted only to those species which produce large ascocarps on sand grains. Consequently, these modifications may possibly be a protective adaptation preventing mechanical damage.

In the other genera studied but not reported here, various peridial structures were observed. However, within a genus, species have a common peridial structure, while species in different genera may have similar peridial structures. These observations suggest that peridial structure is of value as a generic character though it cannot be used as a key character.

\section{c) Taxonomic emendation}

In general, conidium development has been considered to give useful information about the taxonomy of ascomycete teleomorphs. Similarities or differences in conidium development may indicate the affinities of ascomycete teleomorphs. Therefore, the appendage ontogeny which is seen to be correlated with conidium development should be considered to be of primary importance in the taxonomy of the Halosphaeriaceae. The fact that peridial structure in some genera is also correlated with appendage ontogeny supports this conclusion.

From the results presented, the taxonomic proposals made by Jones and Moss (1978, 1980), R. G. Johnson (1980) and Jones et al. (1983) are considered to be proper in delimiting genera in the Halosphaeriaceae on the basis of ascospore appendage ontogeny.

Recently, Jones et al. (1983), on the basis of the ascospore appendage ontogeny, established the new genera Kohlmeyeriella Jones et al. and Nereiospora Jones et al. They transferred $C$. tubulata Kohlm. into the former and both C. cristata (Kohlm.) Kohlm. and C. comata (Kohlm.) Kohlm. into the latter. C. trifurcata was reassigned to the genus Arenariomyces
Höhnk ex Jones. These species have been shown to have different types of appendages from those of other Corollospora species (Jones and Moss 1978, 1980). Our conclusions support these taxonomic proposals.

Taxonomic revision of the genus Halosphaeria was recently presented by Jones et al. (1984). Their work which emphasizes ascospore appendage ontogeny and proposes several taxonomical changes of the Halosphaeria species is also in agreement with the views presented in this paper. However, we have so little information about life histories of Halosphaeria species, that in this study we use the earlier name Halosphaeria mediosetigera instead of Halosphaeriopsis mediosetigera (Cribb et Cribb) Johnson.

\section{Geographical distribution}

There is a paucity of distributional information on the occurrence of marine fungi and there is a danger of drawing conclusions from too little information. However, we present preliminary data on the geographical distributions of $C$. pulchella, $C$. intermedia and $H$. mediosetigera which are shown in Figures 30 to 32. Distribution of teleomorphs and anamorphs were plotted with circles and crosses, respectively. Stars indicate the places where the strains were collected, following the confirmation of both teleomorphs and anamorphs in culture.

From the three distribution maps, teleomorphs are found to be distributed in regions with lower temperatures, while anamorphs are found in regions with higher temperatures. In the intermediate regions, both teleomorphs and anamorphs are found. With respect to $C$. intermedia, there is little information about its distribution (Fig. 31), so more extended research accompanied with cultural studies are needed. H. mediosetigera and T. achrasporum are so peculiar in their distribution that anamorphs occur throughout a much wider range of environmental conditions than teleomorphs and that no anamorph has been found along the west coast of North Ameri$\mathrm{ca}$, in spite of the teleomorph occurring there (Fig. $32)$.

Figs 24-29. Ascospores and ascocarp peridial structures of Corollospora species.

Figs 24, 25. Light microscope and scanning electron micrographs. Ascospore and peridium of Corollospora sp. 1. Figs 26, 27. Light microscope and scanning electron micrographs. Ascospore and peridium of Corollospora sp. 2. Figs 28, 29. Light micrographs. Ascospore and peridium of Corollospora sp. 3.

Bar lines: Figs 24, $26=20 \mu \mathrm{m}$; Figs $25,27,29=10 \mu \mathrm{m}$; Fig. $28=40 \mu \mathrm{m}$. 


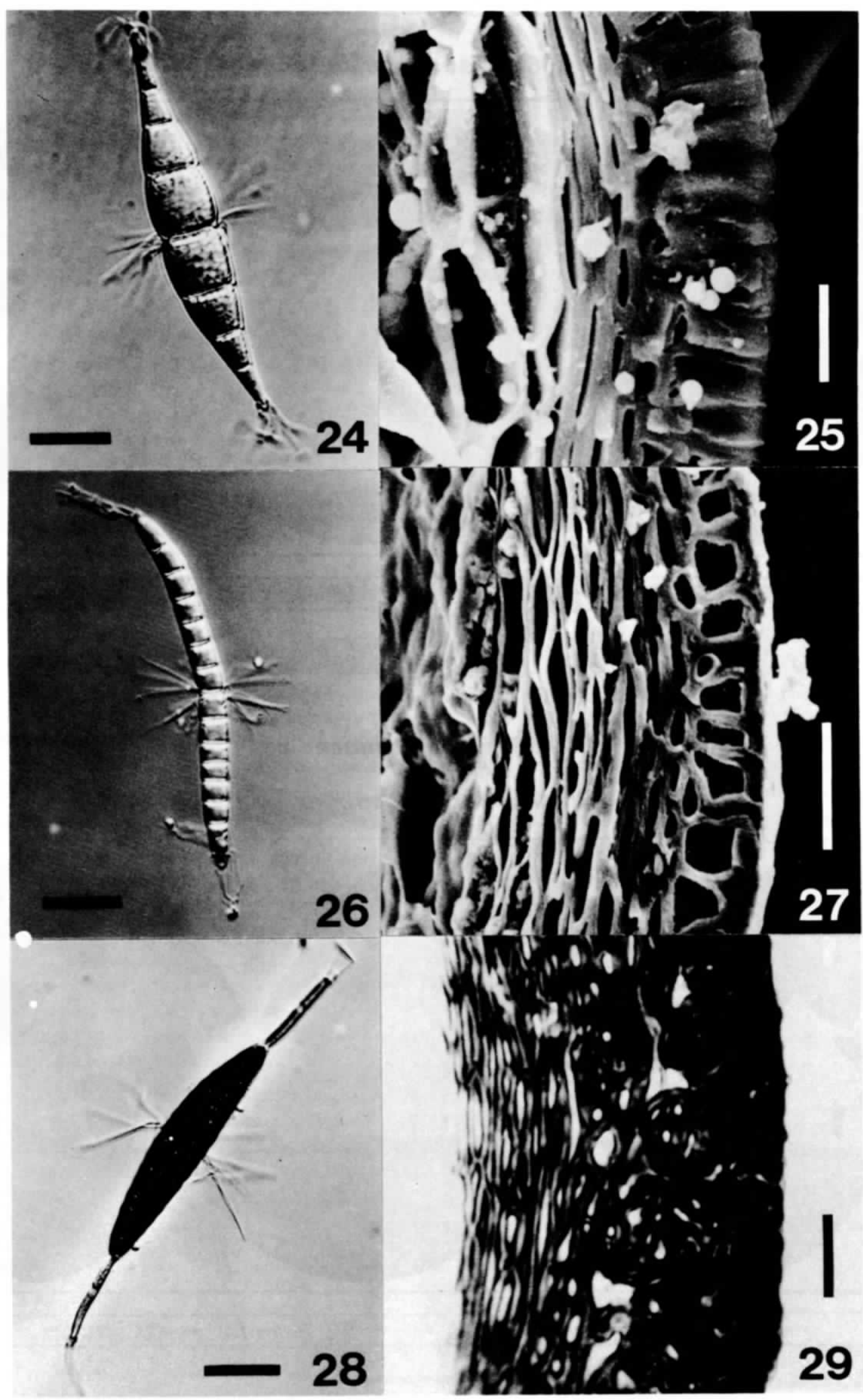




\section{- Corollospora pulchella}

\section{× Clavatospora bulbosa}

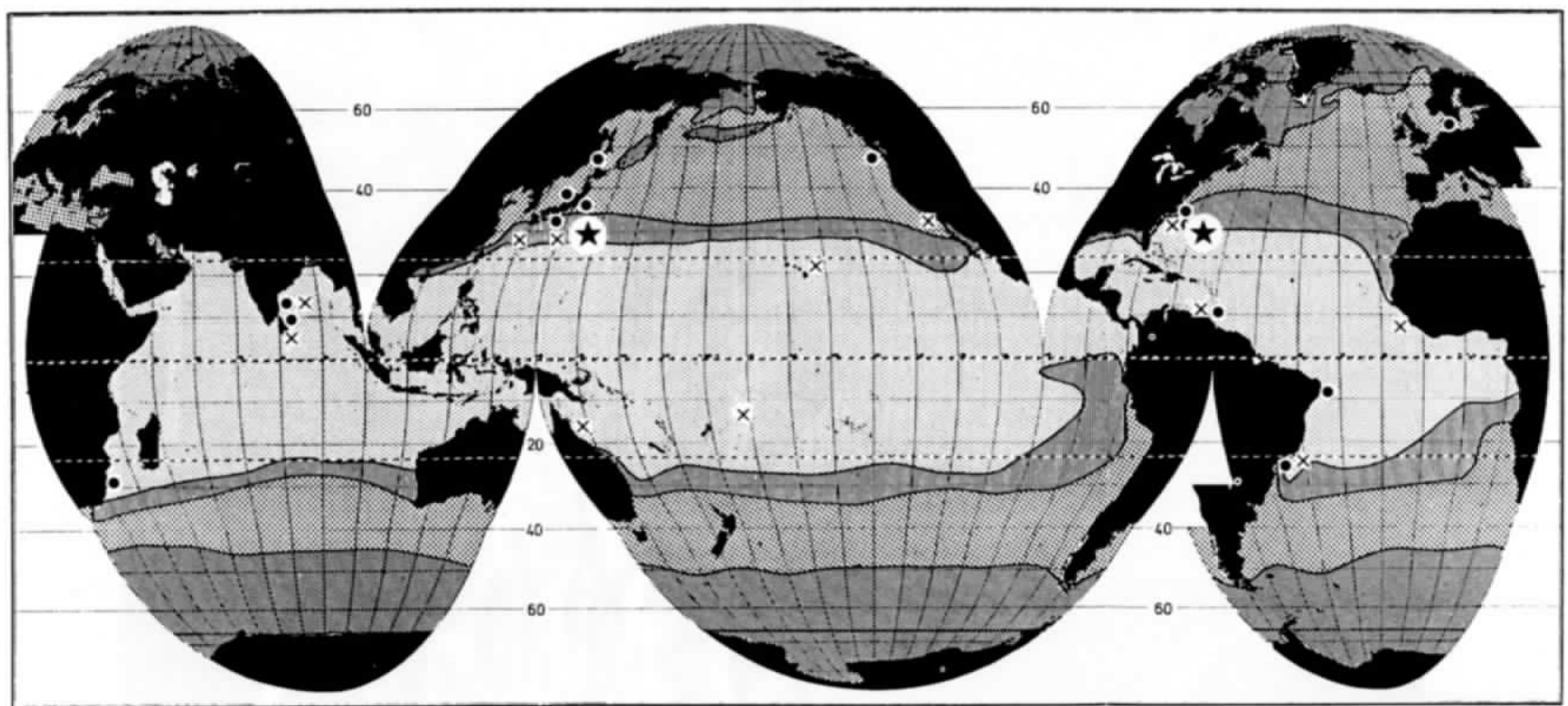

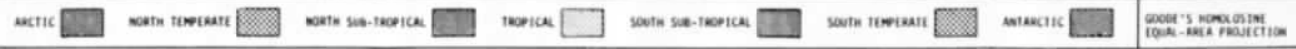

Fig. 30 .

\section{- Corollospora intermedla}

\section{$\times$ Varicosporina sp.}

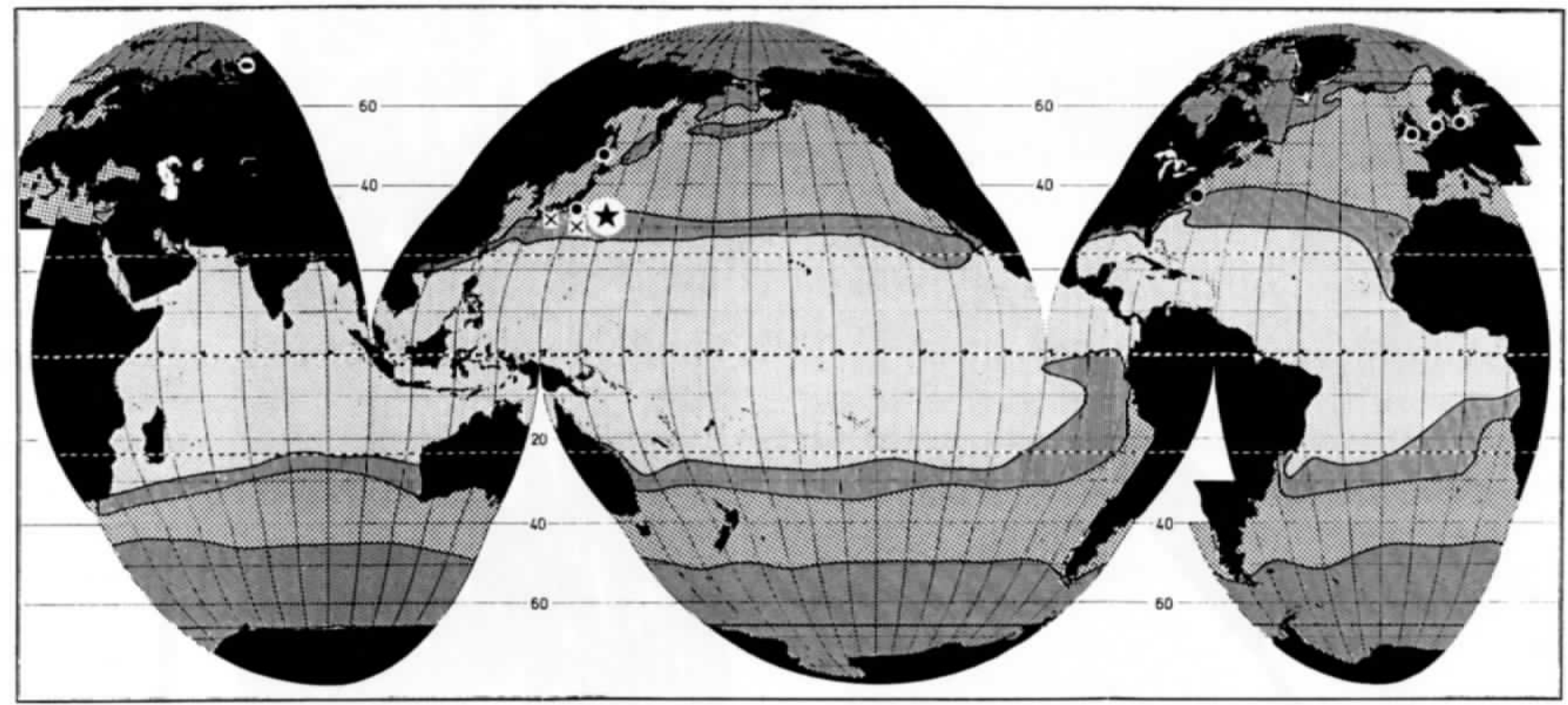

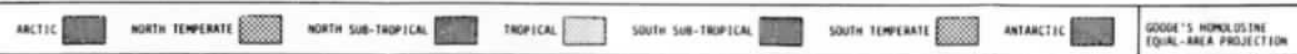

Fig. 31.

Figs 30-32. Geographical distributions of three teleomorph-anamorph species of halosphaeriaceous fungi [Teleomorph strain (circle), Anamorph strain (cross), Holomorph strain (star)] plotted on Hughes' zonal ocean map (Hughes, 1974).

Fig. 30. Corollospora pulchella - Clavatospora bulbosa. Fig. 31. Corollospora intermedia - Varicosporina sp. Fig. 32. Halosphaeria mediosetigera - Trichocladium achrasporum. 


\section{- Halosphaeria mediosetigera}

\section{$\times$ Trichocladium achrasporum}

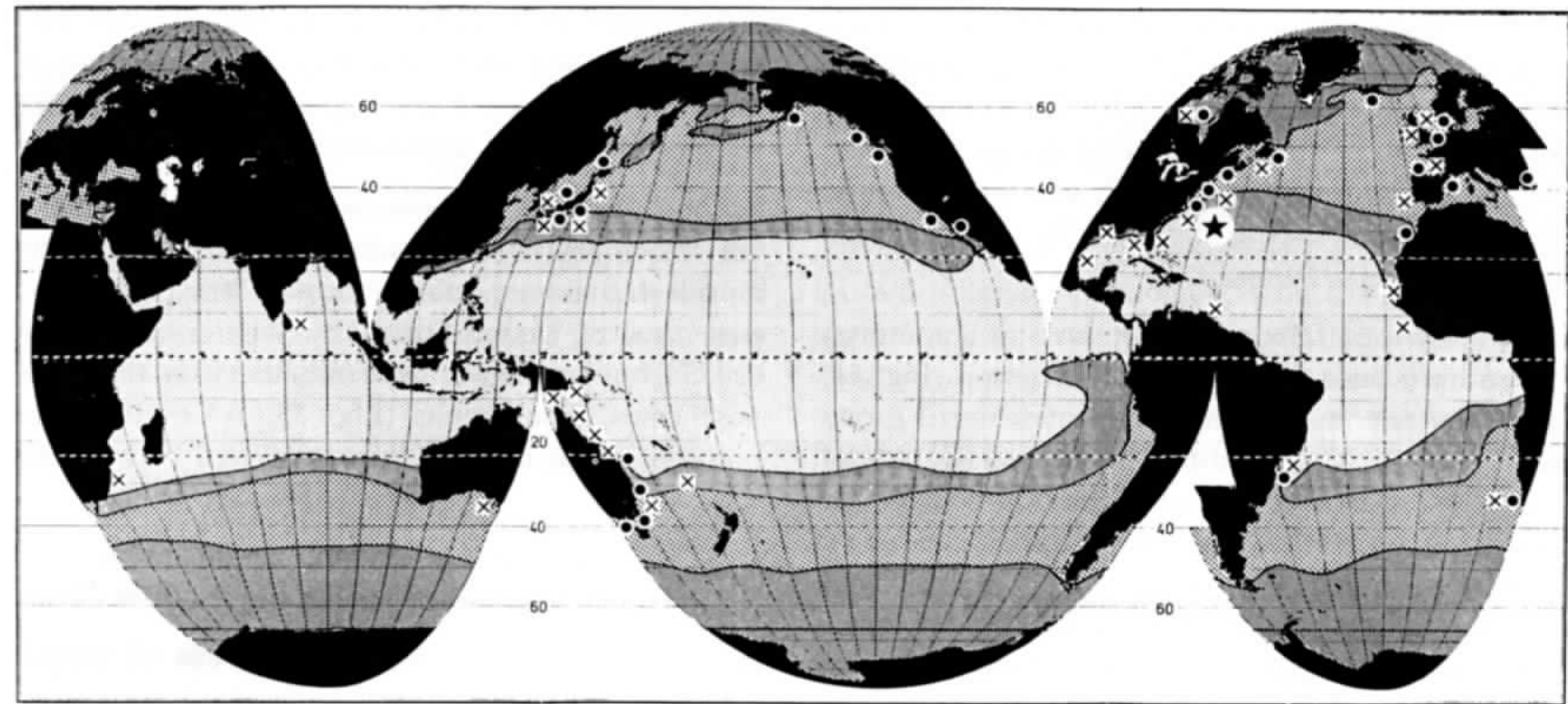

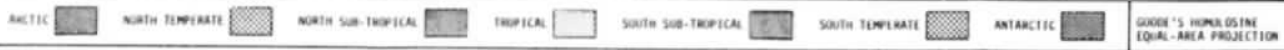

Fig. 32 .

From these observations, it is now considered that there are three types of the life histories in these fungi: 1) only teleomorph, 2) both teleomorph and anamorph, and 3) anamorph only.

In order to support this hypothesis, growth and reproductive properties of the strains of the above three life history types have been investigated. The teleomorph strains are those which are derived from ascospores and never produce conidia; the holo- morph strains are those which are derived from ascospores or conidia and turn into anamorph or teleomorph respectively; and the anamorph strains are those which are derived from the conidia and never produce teleomorph reproductive structures.

The results are illustrated graphically in Figures 33 to 35. From the graphs (Figs 33, A-C) on C. pulchella $-\mathrm{Cl}$. bulbosa, it appears that the teleomorph strains show optimum growth at about $30^{\circ} \mathrm{C}$ with no
A

c. pulchella

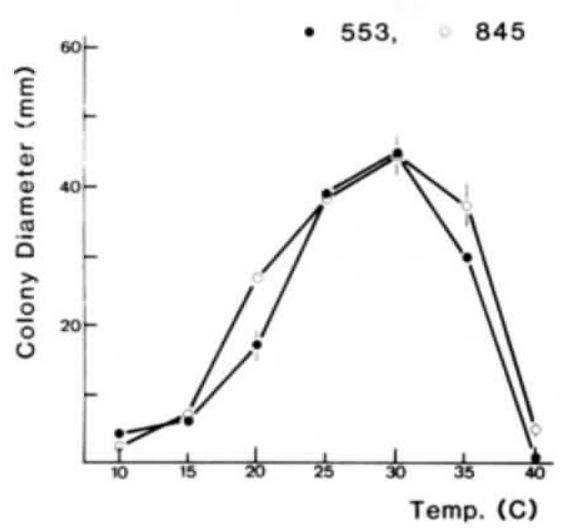

B

C. pulchella - Clav. bulbosa

- $801, \triangle 820$

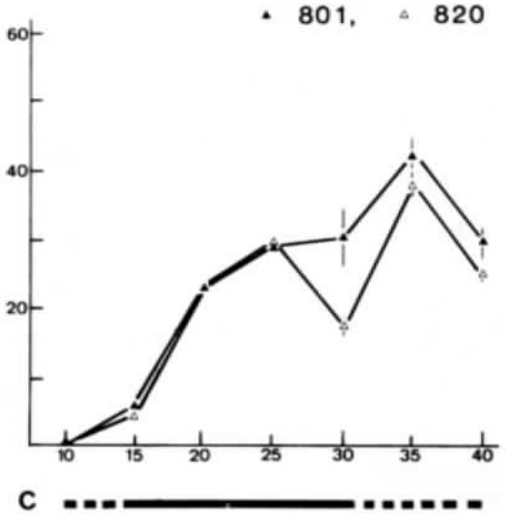

\section{Clav. bulbosa}

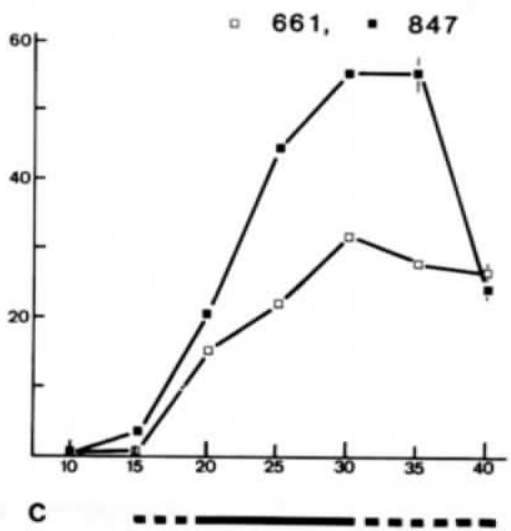

Fig. 33. Hyphal growth and reproductive responses of Corollospora pulchella and Clavatospora bulbosa to temperature (C, bars indicate conidium production).

A. Teleomorph strains (AN-553, 845). B. Holomorph strains (AN-801, 820). C. Anamorph strains (AN-661, 847). 
growth at $40{ }^{\circ} \mathrm{C}$ (Fig. 33, A). On the other hand, anamorph strains show optimal growth at 30 to $35^{\circ} \mathrm{C}$, and fairly good growth was observed even at $40^{\circ} \mathrm{C}$ (Fig. 33, C). The strains provided with both morphs show two peaks in their growth curve and it appears as if they had properties of both teleomorph and anamorph strains (Fig. 33, B). The conidial productivity of these strains, indicated by bars under the graphs of Figures 33, B and C, also indicates the tendency for anamorph strains to be more adapted to higher temperatures.

In $C$. intermedia teleomorph strains and holomorph strains have been found so far. The graph (Fig. 34, A) of the teleomorph strain indicates that it grows well below $35^{\circ} \mathrm{C}$ and best at $25^{\circ} \mathrm{C}$, and perithecial production was observed between 15 and $25^{\circ} \mathrm{C}$. On the other hand, the holomorph strains (Fig. 34, B) grow well at above $15^{\circ} \mathrm{C}$, and optimum growth temperature was around $35^{\circ} \mathrm{C}$. Conidia were produced above $15{ }^{\circ} \mathrm{C}$ and perithecial initials developed between 25 and $35^{\circ} \mathrm{C}$, but they did not mature at these temperatures. They may require some factors responsible for the maturation of perithecia.

In the isolates of Halosphaeria mediosetigera, there are teleomorph and anamorph strains. The holomorph strains were isolated for the Chesapeake Bay, east coast of United States, by Shearer and Crane (1977), but have never been obtained from the Japanese coast. The graphs (Fig. 35, A) of the teleomorph strains indicate they grow well between 10

\section{A}

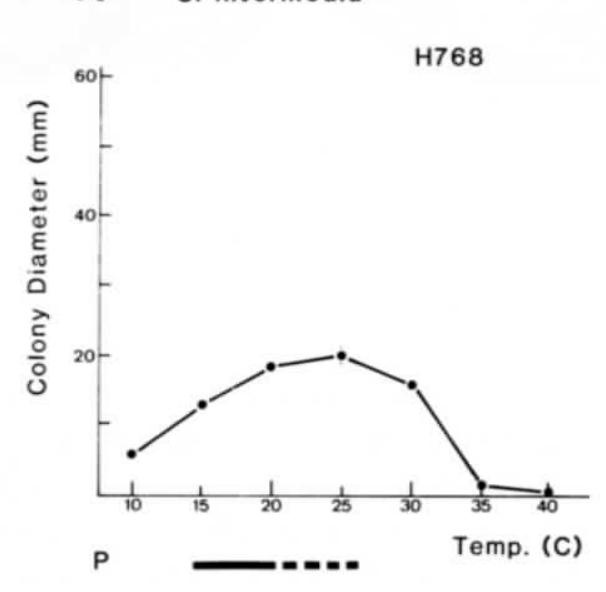

B

c. intermedia - Varicosporina sp.

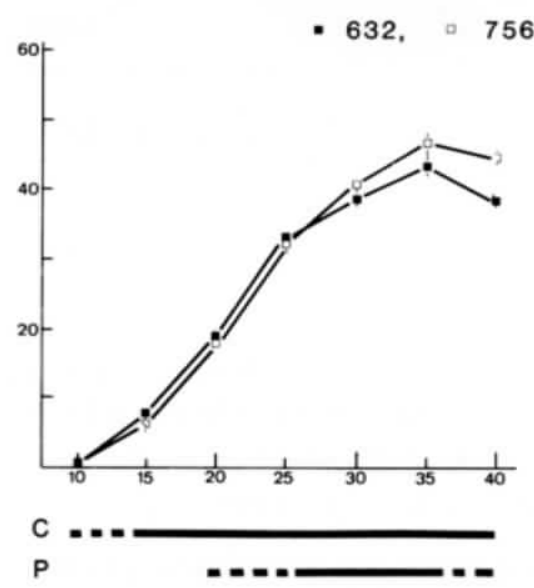

Fig. 34. Hyphal growth and reproductive responses of Corollospora intermedia and Varicosporina sp. to temperature (P, bars indicate perithecium production; $\mathrm{C}$, bars indicate conidium production).

A. Teleomorph strain (H-768). B. Holomorph strains (AN-632, 756).

A H. mediosetigera

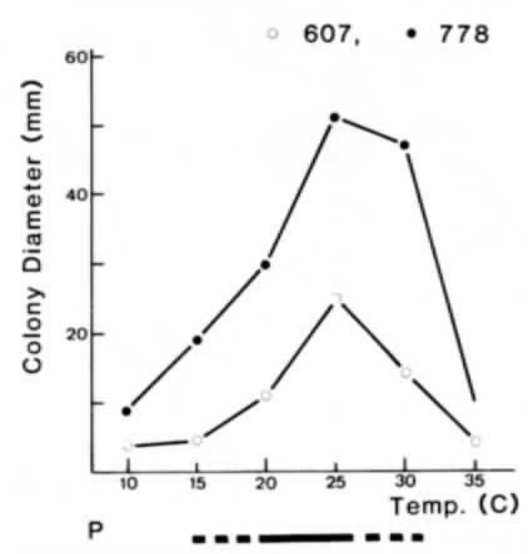

B
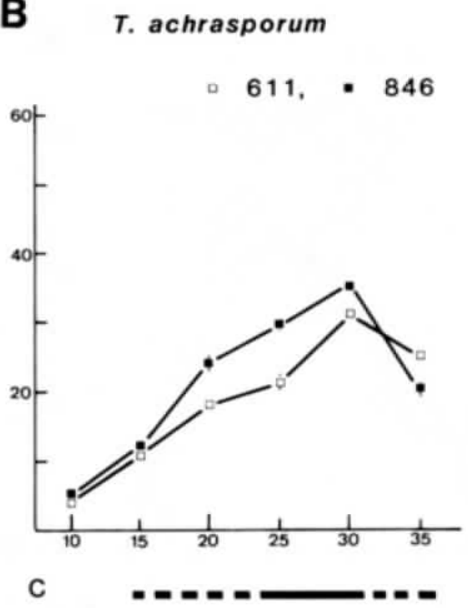

Fig. 35. Hyphal growth and reproductive responses of Halospharia mediosetigera and Trichocladium achrasporum to temperature (P, bars indicate perithecium production; $\mathrm{C}$, bars indicate conidium production).

A. Teleomorph strains (AN-607, 778). B. Anamorph strains (AN-611, 846). 
and $35^{\circ} \mathrm{C}$, and optimum growth temperature was around $25^{\circ} \mathrm{C}$. Perithecia were produced at 15 to $30^{\circ} \mathrm{C}$. The anamorph strains (Fig. 35, B) grow well above $10^{\circ} \mathrm{C}$ and best at $30^{\circ} \mathrm{C}$. Even at $35^{\circ} \mathrm{C}$, they show fairly good growth compared with the teleomorph strains. The better conidial production was observed at 25 and $30^{\circ} \mathrm{C}$.

From these results, it is apparent that the teleomorph strains are comparatively adapted to lower temperatures, anamorph strains are adapted to the higher temperatures and strains provided with both morphs appear to have intermediate properties, as shown in $\mathrm{C}$. pulchella - Cl. bulbosa.

\section{Seasonal alternation of morphs}

Season dependent alternation of morphs in C. intermedia is discussed below.

Figure 36 shows the occurrence of ascospores and conidia in the foam samples collected at Shirahama beach from 1980 through 1983 . The graphs show the average atmospheric and seawater temperature at Nabeta Bay, near to Shirahama beach, measured by the Shimoda Marine Research Center, The University of Tsukuba, from 1977 through 1981.

From this graph, it is apparent that the teleomorph stage occurs during winter, from February to April, and the Varicosporina sp. anamorph occurs in the warmer seasons, from spring to autumn. It is also evident that conidia were observed only when the atmospheric temperature was above $15^{\circ} \mathrm{C}$. By cultural

Occurrence of $C$. intermedia spores

in the foam at Shirahama beach.

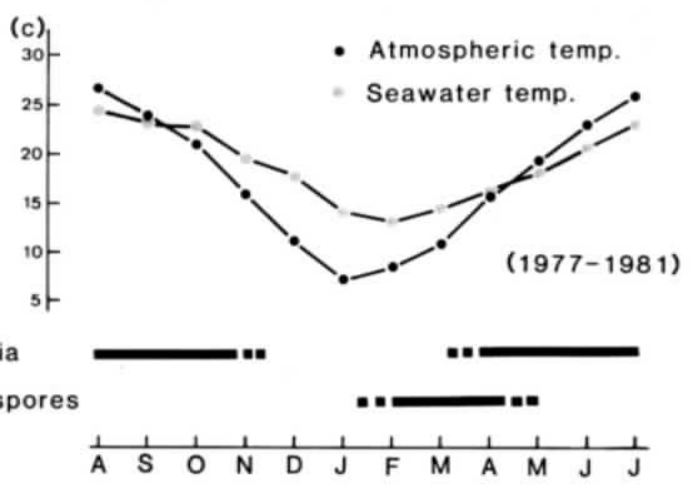

Fig. 36. Seasonal occurrence (indicated with bars) of ascospores and conidia of Corollospora intermedia in sea foam at Shirahama beach. (Graphs showing monthly mean atmospheric and seawater temperatures from 1977 through 1981). experiments, conidia production above $15^{\circ} \mathrm{C}$ was confirmed. It is interesting to note that conidium occurrence depends on atmospheric temperature, not on seawater temperature. The habitat of $C$. intermedia is found in beach sand which may not be always soaked with seawater.

From these results, alternation of morphs $C$. intermedia appears to depend on the temperature. This is the first record of seasonal alternation of morphs in the marine fungi. Kohlmeyer and Charles (1981) reported a similar phenomenon on the increase and decline of conidial occurrence of Varicosporina ramulosa in marine foam in North Carolina, that is, conidia appear in warmer seasons and disappear in winter (December until March). $V$. ramulosa has sclerocarps instead of ascocarps to survive at extreme conditions. From the similarities in conidial shape and in ecology between $V$. ramulos $a$ and the anamorph of $C$. intermedia, the affinity of $V$. ramulosa with halosphaeriaceous fungi, especially Corollospora species, are strongly suggested. A striking resemblance between ascocarps of Corollospora spp. and sclerocarps of $V$. ramulosa was already noted by Kohlmeyer and Charles (1981). Our findings support the notion of these authors that the sclerocarps are "... modified ascocarps that have permanently lost their sexual capacity and function now as sclerotia."

\section{Conclusion}

From our studies of selected marine fungi, we obtained important information for their taxonomy and ecology, especially their teleomorph-anamorph connections.

Taxonomic characters delimiting genera of the Halosphaeriaceae were reevaluated from the view point of the correlation between the characters both of teleomorphs and anamorphs while the previous arguments about the taxonomy have been repeated only on the basis of the teleomorph characters.

\section{Acknowledgements}

This work was submitted as part of the Doctor thesis by the senior author at The University of Tsukuba. We wish to express our gratitude to Professor E. B. G. Jones and Professor J. J. Kohlmeyer for their criticisms and valuable advice during preparation of the manuscript. Thanks are also due to Dr. K. Schaumann and Dr. N. Nakamura for kindly supplying the strains of Corollospora intermedia and Clavatospora bulbosa. 


\section{References}

Anastasiou, C. J. 1961. Fungi from salt lakes. I. A new species of Clavariopsis. Mycologia 53: 11-6.

Barghoorn, E. S., and D. H. Linder. 1944. Marine fungi: their taxonomy and biology. Farlowia I: 395-467.

Booth, T. 1981. Lignicolous and zoosporic fungi in marine environments of Hudson Bay. Can. J. Bot. 59: 1867-1881.

Booth, T. 1983. Lignicolous marine fungi from São Paulo, Brazil. Can. J. Bot. 61: 488-506.

Cavaliere, A. R. 1966a. Marine Ascomycetes: Ascocarp morphology and its application to taxonomy. I. Amylocarpus Currey, Ceriosporella gen. nov., Lindra Wilson. Nova Hedwigia 10: 387-398.

Cavaliere, A. R. 1966b. Marine Ascomycetes: Ascocarp morphology and its application to taxonomy. II. Didymosporae. Nova Hedwigia 10: 399-424.

Cavaliere, A. R. 1966c. Marine Ascomycetes: Ascocarp morphology and its application to taxonomy. IV. Stromatic species. Nova Hedwigia 10: 438-452.

Cole, G. T., and R. A. Samson. 1979. Techniques for developmental and ultrastructural studies of conidial fungi. In: (G. T. Cole, and R. A. Samson, eds) Patterns of development in conidial fungi. Pitman, London. pp. 127-130.

Gorter, G. J. M. R. 1978. Lignicolous marine fungi on submerged wood from the Atlantic coast of South Africa. Nova Hedwigia 29: $895-903$.

Hughes, G. C. 1974. Geographical distribution of the higher marine fungi. Veröff. Inst. Meeresforsch. Bremerh., Suppl. 5: 419-441.

Johnson, R. G. 1980. Ultrastructure of ascospore appendages of marine Ascomycetes. Bot. Mar. 23: 501-527.

Jones, E. B. G. 1968. The distribution of marine fungi on wood submerged in the sea. In: (A. H. Walters and J. J. Elphick, eds) Biodeterioration of Materials. Elsevier, Amsterdam. pp. $460-485$.

Jones, E. B. G., and S. T. Moss. 1978. Ascospore appendages of marine Ascomycetes: an evaluation of appendages as taxonomic criteria. Mar. Biol. 49: 11-26.

Jones, E. B. G., and S. T. Moss. 1980. Further observations on the taxonomy of the Halosphaeriaceae. Bot. Mar. 23: 483-500.

Jones, E. B. G., R. G. Johnson, and S. T. Moss. 1983. Taxonomic studies of the Halosphaeriaceae: Corollospora Werdermann. Bot. J. Linn. Soc. 87: 193-212.

Jones, E. B. G., R. G. Johnson, and S. T. Moss. 1984.Taxonomic studies of the Halosphaeriaceae: Halosphaeria Linder. Bot. Mar. 27: 129-143.

Kirk, P. W.. Jr. 1983. Direct enumeration of marine arenicolous fungi. Mycologia 75: 670-682.

Koch, J. 1982. Some lignicolous marine fungi from Sri Lanka. Nord. J. Bot. 2: 163-169.
Koch,.J., and E. B. G. Jones. 1983. Vedboende havsvampe fra danske kyster. Svampe 8: 49-65.

Kohlmeyer, J. 1960. Wood-inhabiting marine fungi from the Pacific Northwest and California. Nova Hedwigia 2: 293-343.

Kohlmeyer, J. 1969. Marine fungi of Hawaii including the new genus Helicascus. Can. J. Bot. 47: 1469-1487.

Kohlmeyer, J. 1972. A revision of Halosphaeriaceae. Can. J. Bot. 50: $1951-1963$.

Kohlmeyer, J. 1980. Tropical and subtropical filamentous fungi of the Western Atlantic Ocean. Bot. Mar. 23: 529-540.

Kohlmeyer, J., and T. M. Charles. 1981. Sclerocarps: undescribed propagules in a sand-inhabiting marine fungus. Can. J. Bot. 59: $1787-1791$.

Kohlmeyer, J., and E. Kohlmeyer. 1965, 1969. Icones Fungorum Maris. Cramer, Weinheim and Lehre.

Kohlmeyer, J., and E. Kohlmeyer. 1971. Marine fungi from tropical America and Africa. Mycologia 63: 831-861.

Kohlmeyer, J., and E. Kohlmeyer. 1979. Marine mycology, The higher fungi. Academic Press, New York. 690 pp.

Kumar, S. R. 1973. Marine lignicolous fungi from India. Kavaka I: $73-85$.

Marvanová, L. 1980. New or noteworthy aquatic Hyphomycetes. Clavatospora, Heliscella, Nawawia and Heliscina. Trans. Br. Mycol. Soc. 75: 221-231.

Moss, S. T., and E. B. G. Jones. 1977. Ascospore appendage of marine Ascomycetes: Halosphaeria mediosetigera. Trans. Br. Mycol. Soc, 69: 313-315.

Nakagiri, A., and K. Tubaki. 1982. A new marine ascomycete and its anamorph from Japan. Trans. Mycol. Soc. Japan 23: $101-110$.

Nakagiri, A., and K. Tubaki. 1983. Lindra obtusa, a new marine ascomycete and its Anguillospora anamorph. Mycologia 75: $487-497$.

Schaumann, K. 1975. Marine Pilzfunde von der Norwegischen Rinne, der Barents-See und von den Küsten Westafrikas und der Kanarischen Inseln. Veröff. Inst. Meeresforsch. Bremerh. 15: $183-194$.

Shearer, C. A., and J. L. Crane. 1971. Fungi of the Chesapeake Bay and its tributaries. I. Patuxent River. Mycologia 63: $237-260$.

Shearer, C. A., and J. L. Crane. 1977. Fungi of the Chesapeake Bay and its tributaries. VI. Trichocladium achrasporum, the imperfect state of Halosphaeria mediosetigera, a marine Ascomycete. Mycologia 69: 1218-1223.

Webster, J. and E. Descals. 1979. The teleomorphs of waterborne Hyphomycetes from fresh water. In: (E. B. Kendrick, ed.) The whole fungus. Vol. 2. Nat. Mus. Can., Ottawa. pp. $419-451$. 